\title{
Bacterial cellulose membranes and spheres composite with poly (I-lactic acid) through in situ polymerization
}

\author{
Ericka Cirigo y Pérez*, Guilherme Colla, Luismar Marques Porto \\ From 5th Congress of the Brazilian Biotechnology Society (SBBIOTEC) \\ Florianópolis, Brazil. 10-14 November 2013
}

\section{Background}

Since poly(L-lactic acid) (PLLA) shows great biocompatibility as well as biodegradability [1] and bacterial cellulose (BC) is a high purity biomaterial with unique structural and mechanical properties, composed of cellulose and water [2,3], both are biopolymers with great potential for biomedical applications. This work had the purpose of producing biocomposites with properties that bring together the interesting BC and PLLA attributes. With these in mind, an in situ polymerization in $\mathrm{BC}$ membranes and spheres was made by L-lactic acid polycondensation. The presence of toxic residues in the composite was avoid by not using a catalyst [4] since it was possible to solubilized lactic acid in the $\mathrm{BC}$ hydrogel allowing to take advantage of the auto-polymerization property of this acid $[1,4]$. The characterization of the composite was made by Scanning Electron Microscopy (SEM) and cell viability was evaluated by MTS $[2,5]$.

\section{Methods}

$\mathrm{BC}$ membranes and spheres were produced by culturing Gluconacetobacter hansenii ATCC 23769. For polymerization, commercial L-lactic acid was dehydrated at $105^{\circ}$ $\mathrm{C}$ under vacuum, followed by a three hours prepolymerization step at $150{ }^{\circ} \mathrm{C}$, also under vacuum [4]. When temperature decreased to $75^{\circ} \mathrm{C}, \mathrm{BC}$ membranes and $\mathrm{BC}$ spheres were added. Polymerization took place under vacuum, at $90{ }^{\circ} \mathrm{C}$ and agitated at $300 \mathrm{rpm}$ for 48 hours. Samples were taken each 24 hours, submerged in methanol, washed in distillated water at $30{ }^{\circ} \mathrm{C}$ and $120 \mathrm{rpm}$ for 24 hours and then dried at $45^{\circ} \mathrm{C}$. Microstructure was analyzed by SEM. To evaluate the cell viability,

\footnotetext{
Departament of Chemical Engineering Graduate Program, Federal University
} of Santa Catarina, Florianópolis, Santa Catarina, 88040-900,Brazil cultures of mouse fibroblasts L929 were grown in Dulbecco's Modified Eagle Medium (DMEM) in a humidified atmosphere, at $37{ }^{\circ} \mathrm{C}$ with $5 \% \mathrm{CO}_{2}$. Cell viability was determined using the colorimetric assay MTS [3-(4,5dimethylthiazol-2-yl)-5-(3-carboxymethoxyphenyl)-2-(4sulfophenyl)-2H-tetrazolium]. Cells were seeded in a concentration of $10^{5} \mathrm{cell} / \mathrm{membrane}$ and analyzed after 24 hours. Absorbance at $490 \mathrm{~nm}$ was quantified in a microplate reader [2].

\section{Results and conclusions}

Macroscopically, several properties of the composite biomaterial were observed. Compared with $\mathrm{BC}$ control all samples seemed more rigid, showed a white color when hydrated and a slight brightness when dried. Those properties were more evident within the 48 hours treatment. The SEM images showed evidences of integration between the BC and PLLA. MTS assays showed that there were cell adhesion on the 48 hours samples, but it also showed that there was a significant decrease of cell viability compared with the $\mathrm{BC}$ control, what suggests that cells do not have the same affinity for the biocomposite compared with the pure BC. Besides, shape of the samples was also an important factor since the difference in cell viability was significant between the spheres and the membranes.

\section{Acknowledgements \\ To CNPq, CAPES, FAPESC, FINEP, LCME/UFSC.}

Published: 1 October 2014

References

1. Madhavan Nampoothiri K, Nair NR, John RP: An overview of the recent developments in polylactide (PLA) research. Bioresource Technol 2010, 101(22):8493-8501. 
2. Stumpf TR, Pértile RAN, Rambo CR, Porto LM: Enriched glucose and dextrin mannitol-based media modulates fibroblast behavior on bacterial cellulose membranes. Materials Science and Engineering: C 2013, 33(18):4739-4745.

3. Shah N, UI-Islam M, Khattak WA, Park JK: Overview of bacterial cellulose composites: A multipurpose advanced material. Carbohyd Polym 2013, 98(2):1585-1598

4. Achmad F, Yamane K, Quan S, Kokugan T: Synthesis of polylactic acid by direct polycondensation under vacuum without catalysts, solvents and initiators. Chem Eng J 2009, 151(1-3):342-350.

5. Souza DJ, Sayumi M, Pértile RAN, Porto LM, Pezzin APT: Estudo de biocompósitos de poli(L-ácido láctico) (PLLA) com celulose bacteriana (CB) visando aplicação como membranas biomédicas. XII Congresso Brasileiro de Polímeros - CBPOL 2013 Florianópolis; 2013.

doi:10.1186/1753-6561-8-S4-P56

Cite this article as: y Pérez et al:: Bacterial cellulose membranes and spheres composite with poly (I-lactic acid) through in situ polymerization. BMC Proceedings 2014 8(Suppl 4):P56.

\section{Submit your next manuscript to BioMed Central} and take full advantage of:

- Convenient online submission

- Thorough peer review

- No space constraints or color figure charges

- Immediate publication on acceptance

- Inclusion in PubMed, CAS, Scopus and Google Scholar

- Research which is freely available for redistribution

Submit your manuscript at www.biomedcentral.com/submit 